\section{Harwell Course on Isotopes in Industry}

ThE Isotope School at Harwell is arranging a three-day course, during September 25-27, for directors and senior executives from industry, on the uses to which radioisotopes can be put. The course will include visits to the Harwell reactors and to the Wantage Radiation Laboratories, where research is progressing in the use of large radioactive sources for the irradiation of foodstuffs, pharmaceuticals and other manufactured articles. There will be talks on safety precautions to be taken when using radioactive material, and on aspects of turning an ordinary laboratory into an 'active' laboratory. Lectures will give sufficient background information to enable non-technical executives to appreciate the possibilities of the use of radioisotopes. The emphasis throughout will be on the practical uses of isotopes and irradiation sources in industry. Accommodation can be arranged at Worcester College, Oxford. The fee for the course will be $\mathfrak{£ 3 0}$ inclusive of all accommodation, transport, and meals. Forms of application and further information can be obtained from the Registrar, Isotope School, Atomic Energy Research Establishment, Harwell, Berkshire.

\section{British Museum (Natural History) : Appointments}

DR. W. E. CHINA, keeper of the Department of Entomology in the British Museum (Natural History), has been appointed a deputy chief scientific officer in succession to Dr. H. W. Parker (who has held that office in conjunction with the keepership of zoology); Dr. Francis Charles Fraser has been appointed keeper of the Department of Zoology in succession to Dr. Parker ; and Mr. James David Macdonald a deputy keeper in the Department of Zoology ; all with effect from October 1 .

\section{University News :}

Birmingham

THE following appointments in the University of Birmingham are announced: Dr. W. I. Stephen, to be lecturer in chemistry from October 1; Dr. J. Wilcock, to be lecturer in industrial metallurgy from October 1; W. B. Powell, to be staff fellow in the Department of Physics from November 1 ; Dr. P. C. Harris, to be lecturer in medicine from July 1 ; Dr. K. Brown-Grant, to be lecturer in physiology from August 1. The title of reader in organic chemistry has been conferred on Dr. J. C. Tatlow.

London

Dr. H. C. K. Henderson, senior lecturer at Birkbeck College, has been appointed to the University readership in geography tenable at that College; and the title of reader in physics in the University of London has been conferred on Mr. W. R. S. Garton in respect of his post at the Imperial College of Science and Technology.

Sheffield

A GIFT of $£ 25,000$ has been made to the University of Sheffield by Imperial Chemical Industries, Ltd., towards the cost of building extensions to the Departments of Chemistry and of Fuel Technology and Chemical Engineering. The chemistry block in Brookhill, opened in 1954, was the first new teaching building to be erected under the University's development plan, but its capacity has already been overtaken by the increasing numbers of students. Plans have been prepared for the addition of an east wing with large teaching laboratories and a west wing for staff and research rooms. The first part of these extensions is due to begin this year. The Department of Chemistry is the largest in the University and had more than 550 students during the session 1956-57. The Department has not only to train specialists in chemistry and carry out fundamental research, for which it has acquired a distinguished reputation, but must also provide basic teaching for other students in the four Faculties of Pure Science, Medicine, Engineering and Metallurgy. It is in fact one of the key departments in the training of scientists and technologists. The Department of Fuel Technology and Chemical Engineering has for many years carried out valuable work in very cramped conditions at the University's Applied Science buildings at St. George's Square. In order that work on the efficient use of fuel and other industrial problems may go ahead as rapidly as possible considerable extensions to the Department's premises will soon be put in hand.

\section{Announcements}

Sir Charles Linlicrap, a former director of naval construction of the Admiralty, and Mr. John. Strong, chairman of Quasi-Arc, Ltd., have been re-elected for a second year as president and vice-president, respectively, of the Institute of Welding.

Prof. A. C. Frazer, professor of medical biochemistry and pharmacology in the University of Birmingham, has been re-elected president of the British Food Manufacturing Industries Research Association.

Dr. Ralph W. Phullips, deputy director of the Agriculture Division of the Food and Agriculture Organization of the United Nations, has resigned to take up a new appointment as director of the Division of International Organization Affairs in the Foreign Agricultural Service in the United States Department of Agriculture. Dr. Phillips, a distinguished agriculturalist, has served with the Food and Agriculture Organization for more than tcn years.

THE Royal Society of Edinburgh has awarded a Robert Cormack Bequest Fellowship in astronomy to Miss Patricia R. R. Leslie, of Edinburgh. The Fellowship will be tenable for three years at the Cavendish Laboratory, Cambridge, and Miss Leslie will undertake research there, under Mr. Martin Ryle, into the distribution of the sources of extra-terrestrial radio emission. Miss Leslie is a graduate in pure physies of the University of Edinburgh.

THE following have been elected to office in the Physical Society for the session 1957-58 : President, Prof. N. F. Mott ; Honorary Secretaries, Dr. C. G. Wynne, Dr. H. H. Hopkiss ; Honorary Foreign Secretary, Prof. E. N. da C. Andrade; Honorary Treasurer, A. J. Philpot; Honorary Librarian, Dr. R. W. B. Pearse ; Vice-Presidents, Prof. S. Devons, Prof. F. Llewellyn Jones, Prof. H. Jones, and Dr. K. A. G. Mendelssohn.

THE Chemical Research Laboratory, Teddington, Middlesex, is to hold three open days during October 1-3. Applications from firms for invitations should be sent to the Director not later than August 31 .

Erratum. In the article entitled "Some Recent Advances in Spectroscopy" in Nature of June 29, on p. 1342, col. 2 , line 51, for "lithium-potassium spectrum" read "lithium $K$-spectrum". 